\title{
KEBERAGAMAAN PEDAGANG EMAS DI PASAR SENTRA ANTASARI BANJARMASIN
}

\author{
Oleh : Hafiz Anshari dan Mukhyar Sani
}

\begin{abstract}
Abstrak
Para pedagang emas ini mayoritas beragama Islam. Sebagai umat Islam, mereka tentu saja diwajibkan untuk menjalankan perintah agama dan menjauhi segala larangannya. Dalam menjalankan perintah agama mereka (pedagang) tentu saja yang paling utama adalah mendirikan salat dan membayar zakat, karena hal ini merupakan bagian dari rukun Islam yang wajib dilaksanakan. Apabila tidak dilaksanakan akan mendapat dosa, sebaliknya bila dikerjakan akan mendapat pahala. Di samping itu juga mereka diwajibkan dalam berdagang untuk melakukan perdagangan sesuai dengan ajaran hukum Islam, yakni tidak curang, tidak berbohong. Keberagamaan Pedagang Emas di Pasar Sentra Antasari Banjarmasin di Kecamatan Banjarmasin Tengah ini dibagi menjadi tiga bagian, yakni salat lima waktu, zakat, dan etika pedagang dalam jual beli. Untuk lebih jelasnya akan diuraikan satu persatu sebagai berikut:

Faktor-faktor yang Mempengaruhi Keberagamaan Pedagang Emas di Pasar Sentra Antasari Banjarmasin Berdasarkan hasil penelitian yang penulis lakukan, diketahui ada beberapa faktor yang mempengaruhi keberagamaan pedagang emas di Pasar Sentra Antasari Banjarmasin, yaitu faktor kesadaran beragama pedagang, faktor pendidikan, faktor lingkungan sosial keagamaan, faktor keluarga dan faktor ekonomi.
\end{abstract}

\section{A. Pendahuluan}

Kecamatan Banjarmasin Tengah terdapat salah satu pasar yang bernama Pasar Sentra Antasari Banjarmasin. Pasar ini dalam memulai aktivitasnya dari pagi hari hingga sore. Barang-barang yang diperjualbelikan sangat beragam ada jenis pakaian, emas, sepatu dan sendal, elektronik, makanan dan minuman serta sembako. Adapun barang yang paling banyak diminati oleh pembeli adalah emas.

Para pedagang emas ini mayoritas beragama Islam. Sebagai umat Islam, mereka tentu saja diwajibkan untuk menjalankan perintah agama dan menjauhi segala larangannya. Dalam menjalankan perintah agama mereka (pedagang) tentu saja yang paling utama adalah mendirikan salat dan membayar zakat, karena hal ini merupakan bagian dari rukun Islam yang wajib dilaksanakan. Apabila tidak dilaksanakan akan mendapat dosa, sebaliknya bila dikerjakan akan mendapat pahala. Di samping itu juga mereka diwajibkan dalam berdagang untuk melakukan perdagangan sesuai dengan ajaran hukum Islam, yakni tidak curang, tidak berbohong.

Meskipun semua itu merupakan perintah dan larangan agama yang harus mereka (pedagang) turuti atau wajib dilaksanakan dan dihindari, namun pada kenyataannya masih saja ada yang melanggar perintah tersebut. Semua ini tentu saja ada faktor-faktor yang mempengaruhi. Untuk mengetahui secara jelas keberagamaan pedagang emas tersebut, maka kondisi itu membuat penulis tertarik untuk melakukan sebuah penelitian, sehingga dapat diperoleh gambaran yang sebenarnya tentang keberagamaan pedagang emas di Pasar Sentra Antasari Banjarmasin.

\section{B. Landasan Pustaka}

Harun Nasution menurut pengertian agama berdasarkan asal kata, yaitu al-Din, religi (relegere, religare) dan agama. Al-Din (Semit) berarti undang-undang atau hukum. Kemudian 
dalam bahasa Arab, kata ini mengandung arti menguasai, menundukkan, patuh, utang, balasan, kebiasaan. Sedangkan dari kata religi (Latin) atau relegere berarti mengumpulkan atau membaca. Kemudian religare berarti mengikat. Adapun kata agama terdiri dari ( $a=$ tidak; gam=pergi) mengandung arti tidak pergi, tetap di tempat atau diwarisi turun-temurun.

Bertitik tolak dari pengertian kata-kata tersebut menurut Harun Nasution, intisarinya adalah ikatan. Karena itu agama mengandung arti ikatan yang harus dipegang dan dipatuhi manusia. Ikatan dimaksud berasal dari suatu kekuatan yang lebih tinggi dari manusia sebagai kekuatan ghaib yang tidak dapat ditangkap dengan pancaindera, namun mempunyai pengaruh yang besar sekali terhadap kehidupan manusia sehari-hari.

Sedangkan kata "keberagamaan" diambil dari Bahasa Indonesia, dengan kata dasar "beragama", yang berarti antara lain "mempunyai aturan atau norma atau undang-undang atau menganut suatu agama". Kemudian ditambah dengan awalan "ke" dan akhiran "an" menjadi keberagamaan yang berarti sikap dan perilaku beragama seseorang.

Masalah agama tidak akan mungkin dipisahkan dari kehidupan masyarakat, karena agama itu sendiri ternyata diperlukan dalam kehidupan bermasyarakat. Dalam praktiknya peran agama dalam masyarakat antara lain sebagai berikut: agama sebagai motivator, creator dan inovator, sebagai integrator, sublimator, dan agama sebagai sumber inspirasi budaya bangsa Indonesia.

Memiliki kepercayaan yang sama dan mengamalkannya bersama-sama dalam kelompok masyarakat, amat penting bagi agama. Hanya dengan kebersamaan

kepercayaan-kepercayaan inilah pengamalan-pengamalan tersebut dapat dilestarikan.

Agama mempersatukan kelompok pemeluknya sendiri begitu kuat sehingga apabila ia tidak dianut oleh seluruh atau sebagian besar anggota masyarakat, ia bisa menjadi kekuatan yang mencerai-beraikan, memecah belah dan bahkan mengahancurkan.

Ahli sosiologi kontemporer dari Amerika, Yinger, menyatakan bahwa agama merupakan sistem kepercayaan dan peribadatan yang digunakan oleh berbagai bangsa dalam perjuangan mereka mengatasi persoalan-persoalan tertinggi dalam kehidupan manusia.

Zulfi Mubaraq mengungkapkan bahwa pedagang besar seperti pedagang emas, mata pencaharian mereka lebih berorientasi pada kehidupan duniawi, semakin besar penghasilan dan kekayaan yang diperoleh, maka semakin kecil kecenderungan mereka terhadap agama.

Sedangkan menurut R. Stark dan C.Y Glock, keberagamaan adalah ketaatan dan komitmen terhadap agama yang meliputi beberapa unsur diantaranya yaitu keanggotaan gereja, keyakinan kepada doktrin-doktrin agama yang dianut, etika hidup kehadiran dalam acara peribadatan dan pandangan-pandangan serta lain lagi yang menunjukkan ketaatan terhadap agama. Diantara yang mendasari pengertian keagamaan menyangkut beberapa dimensi, diantaranya sebagai berikut: dimensi keyakinan agama (ideologis), dimensi praktik agama, pengetahuan agama, penghayatan agama, dan dimensi pengalaman agama (konsekkuensial)

Kelima dimensi tersebut memberi kerangka acuan dalam menilai komitmen keagamaan seseorang dengan menganalisa hubungan-hubungan antara dimensi-dimensi tersebut.

Agama Islam memiliki pokok-pokok ajaran yang mencakup seluruh aspek kehidupan manusia. Secara umum ajaran agama itu berisi segala macam pedoman (petunjuk) bagi manusia untuk melaksanakan 
kehidupan mereka dalam segala aspeknya, yaitu:

a. Aspek akidah

Akidah dalam Islam adalah bersifat i'tiqad bathiniyah yang mencakup masalah-masalah yang erat hubungannya dengan rukun iman. Masalah akidah ini secara garis besar ditunjukkan oleh rasulullah saw. dalam sabdanya:

"Iman ialah engkau percaya kepada Allah, Malaikat-malaikat-Nya, Kitab-kitab-Nya, Rasul-rasul-Nya, Hari Akhir, dan percaya adanya ketentuan Allah yang baik maupun yang buruk." ( $\mathrm{H}$. R. Muslim)

Di bidang akidah ini bukan saja pembahasannya tertuju pada masalah-masalah yang wajib diimani, akan tetapi juga meliputi masalah-masalah yang dilarang sebagai lawannya, misalnya syirik (menyekutukan Allah), ingkar dengan adanya Tuhan dan sebagainya. Lazimnya masalah pokok yang menjadi bahasan soal akidah terkait kepada rukun iman yang enam : iman kepada Allah, malaikat-malaikat, kitab-kitab, rasul-rasul, hari akhir, dan iman kepada qadha dan qadarNya.

\section{b. Aspek syariah}

$$
\text { Syari'ah dalam Islam }
$$

berhubungan erat dengan amal lahir dalam rangka mentaati semua peraturan/hukum Allah guna mengatur hubungan antara manusia dengan Tuhannya dan mengatur pergaulan hidup antara sesama manusia.Hal ini dijelaskan dalam sabda Nabi saw.:

"Islam ialah menyembah kepada Allah dan tidak menyekutukan-Nya dengan suatu apapun, mendirikan salat, menunaikan zakat yang difardhukan dan berpuasa di bulan Ramadhan." (H. R. Bukhari)

Hadis tersebut di atas mencerminkan hubungan antara manusia dengan Allah swt. Artinya masalah-masalah yang berhubungan dengan masalah syari'ah bukan saja terbatas pada ibadah kepada Allah, akan tetapi masalah-masalah yang berkenaan dengan pergaulan hidup antara sesama manusia diperlukan juga. Seperti hukum jual beli, berumah tangga, warisan, kepemimpinan, dan amal-amal shaleh lainnya. Demikian juga larangan-larangan Allah seperti minum-minuman keras, berzina, mencuri, berbohong, berjudi dan sebagainya. Lazimnya bahasan dibidang ini banyak terkait dengan rukun Islam yang lima, syahadat, shalat, puasa, zakat, dan naik haji, disa,ping masalah-masalah yang erat relevansinya dengan masalah tersebut.

\section{c. Aspek akhlak}

Masalah akhlak dalam aktivitas dakwah merupakan pelengkap saja, yakni untuk melengkapi keimanan dan keislaman seseorang. Meskipun akhlak ini berfungsi sebagai pelengkap, bukan berarti masalah akhlak kurang penting dibandingkan dengan masalah keimanan dan keislaman, akan tetapi akhlak adalah sebagai penyempurna keimanan dan keislaman.Dari Abu Hurairah ra. berkata: Rasulullah saw. Bersabda, artinya "Sesungguhnya aku diutus untuk menyempurnakan akhlak yang mulia. Ke dalam masalah ini termasuk masalah sabar, syukur, jujur, qana'aah, tamak atau rakus, bohong atau berdusta dan lain-lain.

Kondisi kehidupan beragama seseorang dapatlah dilihat dari latar belakang pengalaman kehidupan beragama yang diperolehnya. Di samping itu baik tidaknya pengalaman agama seseorang pasti dipengaruhi oleh beberapa faktor. Faktor itu terdiri dari faktor intern dan faktor ekstern.

\section{a. Faktor intern}

Faktor intern di sini hanyalah berkenaan dengan kesadaran beragama. Di mana pengalaman agama tidaklah timbul dengan sendirinya, namun faktor yang sangat mempengaruhi dan yang paling menentukan adalah keimanan seseorang, yang dari iman itu timbul kemauan untuk mengamalkan ajaran agama dengan baik.

Dari keterangan tersebut, maka dapat dikatakan bahwa faktor keimanan 
sangat menentukan terhadap kehidupan beragama seseorang, apabila imannya kuat maka pengalaman agamanya juga baik, sebaliknya bila imannya lemah maka pengalaman agamanya juga kurang baik.

\section{b. Faktor ekstern}

1) Faktor pendidikan

2) Faktor lingkungan sosial keagamaan

3) Faktor keluarga

4) Faktor ekonomi

Agama Islam mengajarkan kepada para pemeluknya agar senantiasa mengingat Allah dengan melakukan salat.Islam dalam sumber ajarannya, AlQuran dan Sunnah, amat memperhatikan tentang salat. Dalam Islam, salat merupakan perintah yang diutamakan, merupakan kewajiban yang harus ditunaikan, dan sangat diancam bagi yang meninggalkannya. Ia adalah pilar agama, kunci surga, amal yang paling baik, dan merupakan perbuatan orang mukmin yang pertama-tama yang akan dihisap pada hari kiamat nanti.

Salat adalah ibadat yang paling utama untuk membuktikan keislaman seseorang. Untuk mengukur keimanan seseorang, dapat dilihat kerajinan dan keikhlasan dalam mengerjakan salat. Islam memandang salat sebagai tiang agama dan intisari Islam terletak pada salat, sebab dalam salat tersimpul seluruh rukun agama.

Salat menjadi cahaya terang keyakinan, obat pelipur berbagai penyakit di dalam dada, dan pengendali segala permasalahan yang membelenggu kehidupan manusia. Oleh karenanya, salat dapat mencegah perilaku keji dan mungkar. Allah berfirman:

"Sesungguhnya salat itu mencegah dari (perbuatan- perbuatan) keji dan mungkar."(Q.S. Al-Ankabut : 45)

AlQuran mengancam dengan siksaan neraka Wail dan kebinasaan bagi orang yang melalaikan salat sehingga lewat waktunya. Allah swt. berfirman:
"Maka kecelakaanlah bagi orang-orang yang salat, (yaitu) orang-orang yang lalai dari salatnya”. (Q.S. Al-Maa'uun: 4-5)

Zakat suatu ibadah yang penting pula. Kerap kali dalam AlQuran Allah menerangkan zakat beriringan dengan menerangkan salat. Pada 82 tempat Allah menyebut zakat beriringan dengan urusan salat. Ini menunjukkan bahwa antara zakat dengan salat mempunyai hubungan yang erat sekali dalam hal keutamaannya.Zakat yang merupakan ibadah maaliyah dan salat merupakan ibadah badaniyah. Seluruh ulama salaf dan khalaf menetapkan bahwa mengingkari hukum zakat, yakni mengingkari wajibnya menyebabkan dihukum kufur.

Zakat mengandung beberapa hikmah, baik bagi perseorangan maupun masyarakat. Di antara hikmah dan faedah zakat itu adalah:

a. Mendidik jiwa manusia suka berkorban dan membersihkan jiwa dari sifat-sifat kikir dan bakhil.

b. Zakat mengandung arti rasa kebersamaan yang memikirkan nasib manusia dalam suasana persaudaraan.

c. Zakat memberi arti bahwa manusia itu bukan hidup untuk dirinya sendiri.

d. Seorang muslim harus mempunyai sifat-sifat baik dalam hidup perseorangan yakni murah hati, penderma, dan penyayang.

e. Zakat dapat menjaga timbulnya rasa dengki, iri hati dan menghilangkan jurang pemisah antara si miskin dengan si kaya.

f. Zakat bersifat sosialistis, karena meringankan beban fakir miskin dan meratakan nikmat Allah yang diberikan kepada manusia.

Salah satu profesi yang dianjurkan dalam Islam bahkan sering tersebut dalam AlQuran dan Sunnah adalah profesi pedagang. Karenanya banyak sekali sahabat Rasulullah shallallahu alaihi wasallam berprofesi menjadi pedagang. Hanya saja, di dalam Islam setiap profesi yang dibenarkan untuk ditempuh tujuannya bukan 
semata-mata untuk menghasilkan uang atau meraih kekayaan. Akan tetapi yang jauh lebih penting daripada itu adalah untuk mendapatkan keberkahan dari hasil jerih payahnya. Dan keberkahan dari harta bukan dinilai dari kuantitasnya akan tetapi dinilai dari kualitas harta tersebut, darimana dia peroleh dan kemana dia belanjakan.

Sisi kehidupan Nabi Muhammad saw. yang kurang mendapat sorotan adalah karirnya sebagai pedagang dan pengusaha. Dalam literatur dan kisah di sekitar masa mudanya, nabi banyak dilukiskan sebagai al-amin, ash-shidiq, dan pernah mengikuti pamannya berdagang ke Syam dan Syiria.Prasyarat untuk meraih keberkahan dalam berdagang maka harus memperhatikan prinsip etika yang telah digariskan dalam Islam, antara lain jujur dalam takaran, menjual barang yang baik mutunya, dilarang menggunakan sumpah, bermurah hati, dan membangun hubungan yang baik.

\section{Metode Penelitian}

Jenis penelitian yang digunakan dalam penulisan ini adalah penelitian lapangan (Field Research)yang bersifat kualitatif deskriptif dengan mengambil lokasi Pusat Perbelanjaan Pasan Sentra Antasari Banjarmain.

Mengingat banyaknya populasi yang ada, maka dalam penelitian ini penulis perlu untuk menarik sampel secara random sampling, yang ditentukan secara acak sesuai dengan keperluan. Dalam penelitian ini sampel penelitian ditetapkan berjumlah 30 orang.

Sumber data dalam penelitian ini terdiri dari responden dan informan. Jadi informan dalam penelitian ini ialah terdiri dari Pegawai pemerintah/dinas instansi dan Pengelola mesjid.

Subjek penelitian ini adalah pedagang emas di Pasar Sentra Antasari Banjarmasin dan objek penelitiannya adalahkeberagamaan pedagangemas dan faktor-faktor yang mempengaruhi keberagamaan pedagang emas di Pasar Sentra Antasari Banjarmasin.
Teknik pengumpulan data yang digunakan adalah observasi, wawancara dan dokumenter.

\section{Gambaran Singkat Tentang Pasar Sentra Antasari Banjarmasin}

Dimana pun pasar merupakan salah satu sarana penduduk untuk melakukan berbagai transaksi jual beli yakni bagi pembeli yang membutuhkan berbagai kebutuhan hidupnya dan keluarganya untuk memenuhi berbagai keperluan hidup. Sebab di pasar terdapat berbagai kebutuhan hidup rumah tangga yang diperlukan masyarakat.

Karena itu pasar merupakan salah satu yang sangat urgen bagi masyarakat, tanpa adanya pasar di suatu daerah, maka umumnya masyarakat akan mengalami kesulitan untuk mencari kebutuhan hidupnya. Atas dasar inilah umumnya di suatu daerah pasti terdapat pasar-pasar untuk memenuhi kebutuhan hidupnya sehari-hari, apalagi daerah yang cukup besar seperti Kecamatan Banjarmasin Tengah banyak terdapat pasar-pasar kecil maupun besar.

Salah satu pasar yang besar di Kecamatan Banjarmasin Tengah ini adalah Pasar Sentra Antasari Banjarmasin yang terdapat di Jalan Pangeran Antasari. Adapun luas Pasar Sentra Antasari Banjarmasin adalah $45.067 \mathrm{~m}^{2}$.

Adapun barang-barang yang diperjualbelikan adalah dari jenis pakaian, sepatu dan sandal, elektronik, emas, makanan dan minuman serta sembako. Singkatnya barang-barang yang diperjualbelikan oleh pedagang Pasar Sentra Antasari Banjarmasin adalah barang-barang kebutuhan masyarakat.

\section{E. Penyajian Data}

1. Keberagamaan Pedagang Emas di Pasar Sentra Antasari Banjarmasin

Uraian mengenai keberagamaan pedagang emas di Pasar Sentra Antasari Banjarmasin yang ada di Kecamatan Banjarmasin Tengah ini dibagi menjadi 
tiga bagian, yakni salat lima waktu, zakat, dan etika pedagang dalam jual beli. Untuk lebih jelasnya akan diuraikan satu persatu sebagai berikut:

a. Salat wajib lima waktu

Para pedagang Pasar Sentra Antasari Banjarmasin umumnya sudah dewasa, karena itu mereka wajib melaksanakan salat wajib lima waktu. Meskipun mereka wajib melaksanakannya, ternyata berdasarkan hasil penelitian sebagian kecil para pedagang masih kurang melaksanakan salat wajib lima waktu tersebut atau meskipun ada pedagang yang melaksanakannya, namun masih ada sebagian mereka yang tidak melaksanakan secara tunai lima waktu.

Hal ini dapat diketahui, sebanyak 21 pedagang yang dijadikan sampel hanya melaksanakan salat wajib lima waktu kadang-kadang saja, dan 9 orang pedagang yang mengakui selalu rutin melaksanakan salat wajib lima waktu. Dari 9 orang pedagang yang mengakui selalu rutin melaksanakan salat wajib lima waktu, di antara mereka ada 2 orang yang memfasilitasi tokonya dengan tempat ibadah. Hal ini disebabkan karena ukuran toko mereka lebih besar dari yang lain.

Adapun alasan pedagang yang hanya kadang-kadang saja melaksanakan salat wajib lima waktu adalah bahwa sebagian pedagang tidak memiliki anak buah (pembantu) dalam berdagang, mereka berdagang hanya sendiri saja menjaga dagangannya dan bila ada pembeli mereka juga melayaninya sendiri saja.

Adapun alasan responden lainnya yang kadang-kadang saja melaksanakan salat wajib lima waktu di samping sibuk berdagang (menjaga dagangan) mereka juga sejak dahulu jarang mendirikan salat, meskipun ada waktu di pasar atau di rumah, biasanya waktu tersebut mereka pergunakan hanya untuk beristirahat dan berkumpul dengan teman-teman sesama pedagang juga atau dengan para keluarga mereka sendiri.
Adapun alasan pedagang yang selalu melaksanakan salat wajib lima waktu secara rutin adalah mereka beranggapan bahwa salat wajib lima waktu suatu kewajiban yang harus dilaksanakan tanpa ada alasan apapun, sebab salat wajib lima waktu itu perintah agama, apabila melaksanakannya akan mendapat imbalan pahala, sebaliknya apabila tidak mengerjakannya akan mendapat ganjaran dosa. Di samping itu, bagi mereka salat wajib lima waktu tidak memberatkan karena dilaksanakan cuma sebentar saja, bahkan dengan melaksanakannya secara tidak langsung kita sambil beristirahat.

1) Zakat

Dari hasil penelitian yang dilakukan, diketahui bahwa seluruh pedagang emas yang menjadi sampel penelitian ini, sebanyak 30 orang pedagang membayar zakat di bulan Ramadhan.

Adapun alasan mereka membayar zakat adalah karena menurut mereka hal ini sudah merupakan kebiasaan mereka sejak kecil, dimana orang tua dan keluarga mendidik mereka untuk selalu membiasakan mereka bersedekah. Karena kebiasaan dan didikan orang tua mereka itulah membawa pengaruh baik hingga sekarang setelah mereka sudah dewasa, yakni mereka selalu membayar zakat di bulan Ramadhan.

2) Etika pedagang dalam jual beli

Adapun yang dimaksud dengan akhlak jual beli dalam penyajian data ini adalah perilaku atau perbuatan para pedagang emas di Pasar Sentra Antasari Banjarmasin yang dijadikan sampel dalam melakukan aktivitas perdagangannya yang berhubungan dengan para pembeli, yakni apakah ia benar-benar jujur, tidak menipu, berdusta atau sebaliknya melakukan ketidakjujuran atau penipuan terhadap pembeli.

Berdasarkan hasil penelitian yang dilakukan, diketahui sebanyak 17 orang pedagang emas di Pasar Sentra Antasari Banjarmasin yang mengakui pernah melakukan ketidakjujuran atau 
penipuan terhadap para pembeli. Penipuan atau ketidakjujuran yang dimaksud dalam berdusta dengan mengatakan bahwa barang tersebut baru padahal sudah lama. Sedangkan 13 pedagang lainnya, mengakui bahwa mereka tidak pernah melakukan penipuan.

Alasan pedagang emas di Pasar Sentra Antasari Banjarmasin yang pernah melakukan penipuan dengan berdusta adalah bahwa pada dasarnya mereka juga tidak ingin berdusta dalam melakukan transaksi perdagangan dengan pembeli. Namun karena menghadapi pembeli yang berbagai macam sifat dan tingkah laku, maka untuk meyakinkan mereka agar tertarik dengan dagangan mereka terpaksa mereka sedikit-sedikit melakukan kebohongan, sebab menurut mereka umumnya para pembeli tanpa kita tambah-tambahi yang baik-baik meskipun berbohong dalam menawarkan atau bertransaksi dengan pembeli selalu saja para pembeli tidak suka membeli barang dagangan kita, karena itu perlu juga menurut para pedagang untuk berbohong untuk meyakinkan para pembeli agar barang dagangannya menjadi disukai, sehingga dibeli oleh pembeli.

Adapun alasan responden (pedagang) yang menyatakan selalu tidak pernah menipu (berbohong) dengan calon pembeli, karena menurut mereka berbohong dalam berdagang hanya akan merugikan mereka sendiri, sebab mungkin saja satu kali atau dua kali kita dapat membohongi para pembeli, namun untuk ketiga kalinya atau kesekian kalinya orang (pembeli) tidak akan percaya lagi kepada kita (pedagang), sehingga dagangan lama-kelamaan akan tidak laku lagi. Selain itu juga dengan berbuat jujur atau tidak melakukan penipuan terhadap pembeli, menurut mereka kita akan dipercayai orang (pembeli) sehingga lama-kelamaan dagangan akan menjadi laku karena para pembeli sudah percaya terhadap kita, hal ini terbukti selama mereka selalu berdagang dengan cara jujur lama-kelamaan dagangan mereka terus bertambah laku yang akhirnya penghasilan mereka terus meningkat dan dapat mencukupi kebutuhan hidup keluarga mereka, bahkan dapat membantu orang lain yang masih ada hubungan keluarga dengan menjadikan mereka karyawan di tokonya.

3) Faktor-faktor yang Mempengaruhi Keberagamaan Pedagang Emas di Pasar Sentra Antasari Banjarmasin

Berdasarkan hasil penelitian yang penulis lakukan, diketahui ada beberapa faktor yang mempengaruhi keberagamaan pedagang emas di Pasar Sentra Antasari Banjarmasin, yaitu faktor kesadaran beragama pedagang, faktor pendidikan, faktor lingkungan sosial keagamaan, faktor keluarga dan faktor ekonomi. Untuk lebih jelasnya akan diuraikan satu persatu sebagai berikut:

a. Kesadaran beragama pedagang

Masalah kesadaran beragama dalam kehidupan seseorang merupakan salah satu faktor penting yang dapat mempengaruhi kehidupan beragamanya, apabila di dalam diri manusia kesadaran beragamanya kurang, maka dapat dipastikan keberagamaannya juga kurang baik, maka akan menimbulkan efek atau pengaruh yang baik pula terhadap keberagamaannnya. Kesadaran beragama di sini erat hubungannya dengan keimanan dalam diri seseorang, yang bukti baik tidaknya iman itu dapat dilihat dari kesadaran beragamanya.

Adapun hubungannya dengan kesadaran beragama, khususnya tentang keimanan para pedagang emas di Pasar Sentra Antasari Banjarmasin, umumnya secara lisan mereka yakni seluruh pedagang atau $100 \%$ pedagang mengakui bahwa mereka beriman dalam arti beriman kepada rukun iman yang enam. Namun ketika ditanya secara spesifik sebanyak 20 orang pedagang mengakui iman mereka turun naik dan 2 orang yang dengan jujur mengatakan iman mereka masih kurang baik, dan 
sebanyak 8 orang yang menyatakan iman mereka sudah mantap/baik.

Bagi para pedagang emas di Pasar Sentra Antasari Banjarmasin yang merasa iman mereka turun naik, mengakui bahwa di saat iman mereka turun, di dalam diri mereka ada rasa malas untuk melaksanakan amal ibadah seperti salat wajib lima waktu, meskipun ada dorongan untuk melaksanakannya namun rasa malas itu lebih mendorong diri mereka. Dalam hal akhlak berdagang pun di saat iman mereka turun, tanpa mereka sadari mereka juga melakukan kebohongan dalam berdagang kepada para pembeli.

Namun apabila di saat keimanan mereka naik, maka dorongan di dalam diri mereka untuk melaksanakan amal ibadah sangat kuat, sehingga dalam keadaan seperti ini mereka mengerjakan amal ibadah seperti salat wajib lima waktu, menunaikan zakat, dan tidak berbohong, karena itu mereka mengakui dengan jujur dalam hal pengamalan agama dalam kehidupan mereka sehari-hari hanya kadang-kadang saja dapat mereka kerjakan, sebab mereka merasa imannya turun naik. Mungkin hal ini menurut mereka disebabkan bisikan syetan lebih dominan dalam diri mereka sehingga mengalahkan bisikan iman atau mungkin juga karena ilmu pengetahuan agama mereka yang kurang.

Adapun mereka yang mengatakan bahwa keadaan iman mereka selama ini stabil bahkan terkadang naik, menurutnya hal ini mungkin karena kesadaran beragama mereka yang sejak kecil sudah dilatih atau dibiasakan dalam kehidupan mereka sehari-hari, sehingga dalam hal pengamalan keagamaan, seperti salat wajib lima waktu selalu mereka kerjakan, zakat selalu mereka tunaikan, bahkan dalam melakukan transaksi perdagangan selalu mereka laksanakan dengan baik.

b. Pendidikan

Berdasarkan hasil wawancara yang penulis lakukan dengan seluruh responden yang dijadikan sampel penelitian, diketahui tingkat pendidikan para pedagang kebanyakan masih rendah, yakni sebanyak 16 orang pedagang yang tingkat pendidikannya hanya lulus SD, sebanyak 7 orang pedagang yang lulus pada tingkat SMP, 2 orang pedagang yang lulus pada tingkat MTs, sebanyak 1 orang pedagang yang lulus pada tingkat SMA dan 4 orang pedagang yang lulus pada tingkat Aliyah.

Dari kenyataan banyaknya pedagang yang hanya menamatkan pendidikan tingkat SD itu, menurut mereka disebabkan karena orang tua mereka dahulu tidak sanggup lagi menyekolahkan ke jenjang pendidikan yang lebih tinggi, sehingga mereka terpaksa hanya menamatkan pada tingkat SD saja. Akibatnya sebagian dari mereka mengakui cukup berpengaruhterhadap keberagamaan mereka, yakni kurangnya (kadang-kadang saja) mereka melaksanakan amal ibadah salat wajib lima waktu, karena kurang mengetahui bahkan ada yang tidak tahu manfaat dari mengamalkan amal ibadah tersebut, karena mereka merasa ilmu pengetahuan yang kurang termasuk pengetahuan agama. Meskipun mereka sudah berusaha untuk menuntut ilmu agama khususnya untuk menambah pengetahuan agama mereka, namun karena kesibukan kerja (berdagang) untuk mencukupi kebutuhan hidupnya dan keluarganya, akhirnya hal itu hanyalah merupakan sekedar niat saja, sedangkan pelaksanaannya masih kurang.

Meskipun tingkat pendidikan dapat berpengaruh terhadap keberagamaan pedagang, yakni pengaruh yang kurang baik bagi keberagamaan mereka, tetapi tidak selalu pedagang yang pendidikannya masih rendah berpengaruh kurang baik terhadap keberagamaan mereka, namun ada juga keberagamaan mereka yang baik, hal ini menurut pedagang disebabkan, antara lain karena mereka berusaha menyempatkan diri untuk menambah pengetahuan agama dengan 
mendengarkan ceramah agama dan mengikuti pengajian-pengajian agama.

Begitu juga alasan yang dikemukakan oleh pedagang yang hanya menamatkan sekolah pada tingkat SMP saja, yang disebabkan karena ketidakmampuan orang tua untuk menyekolahkan mereka ke tingkat yang lebih tinggi. Walaupun begitu mereka tetap bersyukur, karena sekarang sudah dapat meningkatkan pengetahuan ilmu agama, meskipun masih rendah namun mereka tetap bersyukur. Sebab mereka dapat menjalankan amal ibadah, meskipun terkadang tidak tunai, seperti salat wajib lima waktu, namun mereka tetap ada juga melaksanakan/mengamalkan ajaran agama dalam kehidupan mereka dan mereka berusaha untuk meningkatkan iman dan akhlak mereka dalam kehidupan mereka sehari-hari.

Adapun alasan responden yang sudah menamatkan sekolah pada tingkat SMA, hal itu disebabkan karena orang tua mereka dengan gigih menyekolahkan mereka, di samping adanya kemauan mereka untuk terus melanjutkan sekolah, karena itu mereka sampai menamatkan pada tingkat SMA. Karena cukup tingginya mereka menamatkan sekolah, maka pengetahuan mereka tentang masalah agama cukup baik, terutama tentang masalah-masalah amal ibadah seperti thaharah, salat, puasa, zakat, dan haji, di samping itu juga tentang masalah rukun iman yang enam, rukun islam yang lima, termasuk tentang akhlak. Sehingga pengamalan ajaran agama mereka juga baik, yakni seluruhnya mereka rajin menjalankan salat wajib lima waktu, membayar zakat, dan sangat percaya dengan rukun iman dan islam serta selalu berusaha berakhlakul karimah.

Sedangkan pedagang yang lulus pada tingkat MTs sebanyak 1 orang dan pada tingkat Aliyah sebanyak 4 orang, keberagamaan mereka lebih baik daripada pedagang yang lulus pada tingkat SD/SMP/SMA. Mereka secara rutin melaksanakan salat wajib lima waktu dan membayar zakat, serta berakhlak baik dalam jual beli. Hal ini disebabkan karena mereka lebih banyak mendapatkan pelajaran agama dibandingkan pelajaran umum ketika di sekolah.

c. Lingkungan sosial keagamaan

Sebagaimana pasar-pasar lainnya pasti keadaan lingkungannya sangat ramai dikunjungi oleh masyarakat, baik mereka yang ingin berbelanja maupun yang hanya sekedar untuk melihat-lihat atau jalan-jalan saja. Demikian juga keadaan lingkungan Pasar Sentra Antasari Banjarmasin sangat ramai dikunjungi para pembeli maupun mereka yang hanya sekedar jalan-jalan.

Karena ramainya, setiap hari hingga sore harinya di Pasar Sentra Antasari Banjarmasin itu dikunjungi oleh masyarakat, maka umumnya para pedagang emas juga sibuk menawarkan barang dagangannya atau menunggu para pembeli untuk menawar barang-barang yang diperdagangkan atau sebagian pedagang ada juga berharap pembeli yang mau membeli dagangannya, karena kesibukan itulah maka pada umumnya banyak yang melalaikan atau tidak dapat melaksanakan salat pada waktu aktivitas perdagangan dilakukan, mereka yang mengakui hal ini sebanyak 21 orang pedagang dan hanya 9 orang pedagang saja yang selalu rajin beramal ibadah dan akhlak mereka dalam berdagang juga selalu baik dan jujur.

d. Keluarga

Berdasarkan hasil penelitian yang dilakukan, diperoleh data bahwa lingkungan keluarga para pedagang emas di Pasar Sentra Antasari Banjarmasin khususnya dalam masalah kehidupan beragama, belum mengamalkan amal ibadah salat wajib lima waktu. Pedagang yang lingkungan keluarganya belum baik kehidupan beragamanya sebanyak 19 orang dan yang cukup baik pengamalan agamanya sebanyak 11 orang.

Karena banyaknya lingkungan keluarga yang kurang baik itulah, umumnya para pedagang mengakui 
dengan jujur menurut mereka tidak ada yang memberi dorongan terhadap mereka. Di samping itu juga tidak ada yang mereka malui, karena keluarga mereka juga hanya kadang-kadang saja melaksanakan amal ibadah, bahkan ada yang sama sekali tidak mau melaksanakan amal ibadah.

Sebaliknya para pedagang yang lingkungan keluarganya baik dalam menjalankan amal ibadah atau cukup baik dalam mengamalkan ajaran agama, umumnya mempengaruhi juga terhadap pengamalan agama para pedagang itu sendiri, yakni pengaruh ke arah yang baik pula, yakni para pedagang umumnya juga rajin beramal ibadah atau mengamalkan ajaran agama, hal ini terbukti 9 orang pedagang selalu menjalankan salat wajib lima waktu dengan tunai, membayar zakat, dan selalu berusaha berakhlak yang baik dalam menjalankan perdagangan. Semua ini menurut mereka di samping karena kebiasaan mereka sejak kecil yang dididik oleh orang tua mereka untuk selalu mengamalkan ajaran agama dalam kehidupan sehari-harinya, juga karena ada dorongan keluarga serta dorongan mereka sendiri yang ingin selalu menjalankan amal ibadah sebagai bekal hidup mereka di dunia dan di akhirat kelak.

e. Ekonomi

Adapun yang dimaksud dengan ekonomi dalam penelitian ini adalah bahwa karena kesibukan para pedagang dalam mencari nafkah hidup mereka dan keluarga mereka yang menyebabkan mempengaruhi kehidupan beragama mereka.

Berdasarkan hasil penelitian yang dilakukan, diketahui kehidupan ekonomi para pedagang emas di Pasar Sentra Antasari Banjarmasin rata-rata sudah cukup baik maksudnya kehidupan ekonomi mereka yakni penghasilan mereka dalam berdagang sudah mencukupi kebutuhan hidup keluarga mereka sehari-hari, bahkan ada yang berlebihan. Keadaan ekonomi yang cukup ini dialami oleh pedagang yang berjumlah 19 orang. Sedangkan pedagang lainnya yakni berjumlah 11 orang dapat dikatakan bahwa keadaan ekonomi mereka masih sederhana, yakni ekonominya masih pas-pasan hanya untuk memenuhi kebutuhan hidup keluarga mereka saja.

Adapun pedagang yang penghasilannya cukup atau kehidupan ekonominya cukup baik, ternyata tidak mengetahui keberagamaan mereka ke arah yang baik, sebaliknya pengaruhnya kurang baik terhadap keberagamaan mereka, dimana karena kesibukan mereka dalam berdagang membuat mereka lalai atau hanya kadang-kadang saja menjalankan amal ibadah, seperti salat wajib lima waktu. Di samping itu kebanyakan dari mereka hanya mengumpulkan harta saja dan kurang memperhatikan kehidupan beragama mereka. Sedangkan para pedagang yang hanya pas-pasan kehidupan ekonominya ternyata pengaruhnya cukup baikterhadap keberagamaan mereka, alasannya biarpun ekonomi mereka pas-pasan mereka tetap bersyukur dan menjalankan ibadah, sebab dengan beribadah mengharapkan keridhaan Allah akan memberikan rezki lebih buat mereka dan keluarganya.

4) Upaya Dakwah yang Dilakukan Untuk

Membina Keberagamaan Pedagang

Emas di Pasar Sentra Antasari Banjarmasin

Dari hasil penelitian yang dilakukan di lapangan mengenai usaha-usaha untuk meningkatkan keberagamaan para pedagang emas di Pasar Sentra Antasari Banjarmasinbelum dapat dilakukan. Dari hasil wawancara penulis dengan responden kebanyakan dari mereka tidak mengikuti pengajian atau majelis taklim karena lebih banyak menghabiskan waktu untuk berdagang.

Usaha-usaha yang dilakukan untuk membina keberagamaan pedagang emas di Pasar Sentra Antasari Banjarmasin adalah berupa pembinaan secara formal dan nonformal.

Pembinaan secara formal di masyarakat dilakukan oleh Penyuluh 
Agama Honorer (PAH) pada setiap lapisan masyarakat di setiap Kecamatan Banjarmasin Tengah.

Pembinaan secara nonformal dilaksanakan secara umum oleh masyarakat. Namun pedagang merupakan bagian dari masyarakat maka secara tidak langsung akan ikut terbina dalam berbagai kegiatan keagamaan dalam masyarakat.

\section{DAFTAR PUSTAKA}

Abdurrahman, M. Masykuri \& Mokh. Syaiful Bakhri, Kupas Tuntas Shalat Tata Cara Dan Hikmahnya. (Jakarta, Erlangga, 2006).

Agus, Bustanuddin, Al-Islam: Buku Pedoman Kuliah Mahasiswa Untuk Mata Ajaran Pendidikan Agama Islam. (Jakarta, PT Raja Grafindo Persada, 1993).

Anwar, Rosihon, Akhlak Tasawuf.( Bandung, Pustaka Setia, 2010).

Baihaqi, Imam Abu Bakr Ahmad bin Husain, As-Sunan Al-Kubra. Jilid X, (Beirut, Darul Fikri, t.th).

Bukhari, Imam Abu Abdullah Muhammad bin Ismail, Shahih Bukhari. Jilid I, (Beirut, Darul Fikri, 1994).

, Shahih Bukhari. Jilid III,( Beirut, Darul Fikri, 1994).

Daradjat, Zakiah, Ilmu Jiwa Agama. (Jakarta, PT Bulan Bintang, 2005).

Departemen Agama RI., AlQuran dan Terjemahnya. (Bandung, PT Syaamil Cipta Media, 2004).

Departemen P\&K RI., Kamus Besar Bahasa Indonesia. (Jakarta, Balai Pustaka, 1990).

Dimsyaqi, Muhammad Djamaluddin Alqasimy, Mauizatul Mukminin Min Ihya 'Ulumuddin. diterjemahkan oleh Abu Ridha dengan judul, Bimbingan Orang-Orang Mukmin.( Semarang, CV Asy-Syifa', 1993).

Djakfar, Muhammad, Etika Bisnis Dalam Islam.( Malang, UIN Malang Press 2007.)
Fachruddin, Fuad Mohd., Nilai-nilai Dasar Bangunan Islam. (Jakarta, Kalam Mulia, 1992).

Hajjaj, Imam Abu Husain Muslim, Shahih Muslim. Jilid I, (Beirut, Darul Fikri, 2008). Shahih Muslim. Jilid II,( Beirut, Darul Fikri, 2008).

Hakim, Muhammad Nipan Abdul, Menghias Diri Dengan Akhlak Terpuji. (Yogyakarta, Mitra Pustaka, 2000).

http://inaycahayakarunia.blogspot.com /2012/12/dimensi-keberagamaan.ht ml, diakses pada tanggal 11 Juli 2013 jam 11:31AM

Ilyas, Yunahar, Kuliah Aqidah Islam. (Yogyakarta, Lembaga Pengkajian dan Pengamalan Islam, 2000).

Jalaluddin, Psikologi Agama. (Jakarta, PT Raja Grafindo Persada, 2008).

Madjrie, Abdur Rahman, Meluruskan Tauhid. (Bandung, Prima Press Bandung, 1989).

Mubaraq, Zulfi, Sosiologi Agama. (Malang, UIN Maliki Press, 2010).

Munir, Ahmad dan Sudarsono, Dasar-Dasar Agama Islam. (Jakarta, PT Rineka Cipta, 2001).

Nottingham, Elizabeth K., Religion and Society. diterjemahkan oleh Abdul Muis Naharong dengan judul, Agama dan Masyarakat. (Jakarta, Rajawali, 1990).

Qardhawi, Yusuf, Al-Ibadah Fil Islam. diterjemahkan oleh Umar Fanani dengan judul, Ibadah Dalam Islam. (Surabaya, PT Bina Ilmu, 2001).

Rifa'i, Moh., Ilmu Fiqh Islam Lengkap. (Semarang, PT Karya Toha Putra, 1978).

Ritonga, Ahmad Rahman, Akhlak Merakit Hubungan Dengan Sesama Manusia. (Surabaya, Amelia, 2005).

Saurah, Abu 'Isa Muhammad bin 'Isa, Sunan At-Tirmidzi. jilid III, (Beirut, Darul Fikri, 1994).

Sayuthi, Jalaluddin Abd. Rahman bin Abu Bakar, Jami' Ash-Shaghir. juz II,( Mesir, Darul Hujri Kutub Al-Khairiyah, t.th).

Scharf, Betty R., The Sociological Study of Religion. diterjemahkan oleh 
Machnun Husein dengan judul, Syukir, Asmuni, Dasar-dasar Strategi Sosiologi Agama. (Jakarta, Kencana, Dakwah Islam.( Surabaya, Al-Ikhlas, 2004). 1983).

Shiddieqy, Muhammad Hasbi, Kuliah

Tafsir, Ahmad, Pendidikan Agama Dalam Ibadah: Ibadah Ditinjau Dari Segi Hukum Dan Hikmah. (Jakarta, Bulan Bintang, 1994).

Sudarsono, Sepuluh Aspek Agama Islam. (Jakarta, PT Rineka Cipta, 1994). Keluarga. (Bandung, PT Remaja Rosdakarya, 2000).

Yafie, Ali, et al., Fiqh Perdagangan Bebas. (Jakarta Selatan, TERAJU, 2003). 